Milica Đuričić

Faculty of Philology

University of Belgrade
UDC 811.162.4'246.2(497.113)

DOI https://doi.org/10.18485/fid.2017.7.ch18

\title{
THE LANGUAGE OF INSTRUCTION ISSUE IN PRESCHOOLS IN BILINGUAL SETTINGS: THE EXAMPLE OF THE SLOVAK ETHNOLINGUISTIC MINORITY IN STARA PAZOVA
}

У овом раду анализирају се ставови запослених у предшколској установи „Полетарац“ у Старој Пазови, војвођанском месту са српско-словачким билингвизмом, према условима за развој језичким компетенција на поменута два језика. Истраживање је извршено путем анонимног упитника. Главни циљ био је идентификовање проблема са којима се етнолингвиситчке мањине могу сусрести у образовном систему Србије било да је реч о остваривању права на образовање на језику примарне социјализације или о њиховом одрицању тог права. Резултати истраживања указују на недостатке раздвајања деце на основу језика и погрешног става запослених да ће се код детета развијати подједнако језичке компетенције на два језика којима су изложени у својој околини, посебно ако је реч о групи на већинском језику. Иако постоје услови за развој словачко-српског билингвизма, долази се до закључка да би уз додатне стратегије у виду организовања семинара за запослене који раде у билингвалним срединама, као и коришћење приручника са препорукама за рад са децом из мањинских заједница, постојећи услови могли бити значајно унапређени, што би помогло деци која потичи из етнолигвистичких мањина да паралелно негују свој матерњи језик и већински језик, што би им истовремено омогућило очување сопственог језичког и етничког идентитета, као и успешну интеграцију у друштво.

Кључне речи: билингвизам, предшколске установе, српски језик, словачки језик, Стара Пазова.

\section{Introduction}

Preschools may be of crucial importance in the development of bilingualism. The nursery schools may affect not only parents' decisions when it comes to their children's language of instruction but also the very survival of a minority language in the given environment. However, most previous studies on bilingualism do not take into account what nursery school teachers think and how they treat minority children; if they help 
them become bilingual or not. Although several studies about bilingualism and multilingualism in the Serbian Province of Vojvodina (Mikeš, 1996; Mikeš, 2006; Mikeš, 2008; Šimoniova-Černakova, 2007; Đuričić 2014a) have indicated that pre schools play an important role in helping a child become bilingual, little attention has been paid to what nursery school teachers really do in the classroom.

This paper analyzes the attitudes of employees in the preschool "Poletarac" in Stara Pazova, a town in the Serbian Province of Vojvodina, with Serbian-Slovak bilingual residents.

In the first part of this paper, we will briefly discuss the concepts of language shift and language maintenance, types of bilingualism and the role of preschools in developing bilingualism. Then we will describe the conditions for studying both Serbian and Slovak in schools in Stara Pazova. In the second part, we will present the results of qualitative research carried out in the preschool "Poletarac" in this town. Later on, we will emphasize the pedagogical implications of this research and its results.

\section{Theoretical framework}

\subsection{Language shift vs. language maintenance}

Different factors can cause a language shift (mainly those which do not have much to do with the language itself): language ideologies and attitudes toward majority and minority languages (positive or negative); language policy; the education system (the status of a minority language in it); the extent of the use of a minority language in various domains; self-awareness of linguistic and ethnic identities, etc. It is a complex issue we should all care about not only ethnolinguistic minorities, but the whole multiethnic society.

Language maintenance is a complex process and it depends on a lot of factors. Sometimes it is impossible to overcome difficulties that minorities encounter in the majority society when it comes to the educational system and the position of their mother tongue in it. Job opportunities are also very important. In some cases it is recommendable that children speak both minority and majority languages. Unfortunately, in some settings the majority language is essential for getting a job. However, bilingualism is something we should all strive for in the $21^{\text {st }}$ century. 


\section{Types of bilingualism}

"For children, being bilingual or monolingual may affect their identity, social arrangements, schooling, employment. marriage, area of residence, ravel and thinking" (Baker, 2007: 1).

Bilingualism can be additive or subtractive. Mikes (Mikeš, 1996: 11) defines additive bilingualism as bilingualism which does not develop at the expense of the mother tongue but adds to that language, so that its development has a positive effect on the speech and cognitive development of a child. The subtractive bilingualism includes acquiring language competences in a majority language at the expense of a child's mother tongue. In other words, it means neglecting a child's minority language and culture. "The idea is that the second (majority) language should become dominant, or even replace the minority language" (Baker, 2007).

According to Skutnab - Kangas (1991: 7), in terms of language a person should have the following rights: 1. to identify with the mother tongue and to be accepted and respected by members of the majority community; 2. to fully acquire his or her mother tongue; 3. to use his or her mother tongue in official situations and in different domains; 4. to fully master the official language of the country he or she lives in.

The state and parents are crucial for preserving minority languages in the following way: the language education policies, legal framework and financial support, and parents' own decisions on which their children will be instructed, of course, in areas which they can choose (ŠimoniovaČernakova, 2007: 821). However, we should emphasize the fact that a large number of members of the minority communities consciously deny their constitutional right to be educated in their mother tongue, so that they can find employment more easily after finishing school with Serbian as the language of instruction (Filipović, 2011).

\section{The role of preschools in developing bilingualism}

Parents coming from a minority community are sometimes not aware of the fact that there is a risk that children may fail to reach the level of proficiency that is expected from a monolingual child if their children learn the language which is not their mother tongue in a preschool (Skutnab Kangas, 1991: 39). 
Although parents have a great responsibility and their decisions and linguistic practices have a huge influence on the development of a child's bilingualism, other factors also play an important role, such as social and educational conditions for simultaneous acquisition of language proficiency in two languages (De Houwer, 2007). Conditions in the educational system, as well as parents' decisions about the language in which their children will be educated, can have unforeseen consequences both for the child and for the minority language and culture (Đuričić, 2013: 547). Apart from a family, educational institutions should also support the development of linguistic competence on both the majority and the mother tongue of children belonging to minority communities (Đuričić, 2014a: 717). In other words, the development of bilingualism among members of ethnolinguistic minorities demands the cooperation of a family and school environment (Đuričić, 2013: 551). So, Baker (2007: 1) concludes: 'Bilingualism has educational, social, economic and cultural consequences".

Children who are exposed to different cultural patterns and languages in a family or their environment from their early childhood need to preserve their ethnic and linguistic identities. They also need to be actively involved in the majority community in which they live and grow up (Klemenović \& Kamenov: 1998: 324). Developing communication skills both in children's native and second language is essential primarily because of their socialization in a multicultural environment (Mikeš, 1996: 16).

Preschools may be of crucial importance in the development of bilingualism. A nursery school, which brings together children whose native languages are different, provides a good opportunity to overcome language barriers by good organization of educational work and pedagogical activities (Mikeš, 1996: 5). The preschool may affect not only parents' decisions when it comes to their children's language of instruction but also the very survival of the minority language in the given environment in the future.

The preschool teacher plays a significant role in the child's acquisition of language competencies and fostering tolerance in the classroom, especially in ethnically mixed groups (Đuričić, 2014a: 719).

\section{The position of the Slovak language in schools in Stara Pazova}

There is one preschool in Stara Pazova. Groups are divided according to the language of instruction when a child turns three. Till then the 
groups are mixed groups. There are no bilingual groups. It is not a good solution: firstly, because the bilingual groups are better for developing additive bilingualism; secondly, they can help to foster tolerance between the minority and majority children, etc.

There are three primary schools in the town: one with Slovak as the language of instruction and two with Serbian. In those two schools there are no Slovak classes, although, according to the law, they should be offered to children coming from the Slovak ethnolinguistic minority (Đuričić, 2014b: 425).

As far as secondary schools are concerned, there are three schools in which Serbian is the language instruction. However, there Slovak as an optional subject. Since it is an optional subject with just one class per week, students fail to choose it and show motivation due to the fact that the mark is not included in the average mark. Even if they are interested in fostering their language, one class per week is definitely not enough (Đuričić, 2014b: 426).

\section{Research}

Even if there are good conditions for developing bilingualism in a nursery school, it is not a guarantee that a child will reach the same level in two languages which would help him to successfully integrate in the majority society and preserve his or her ethnic and linguistic identities. That is why we have decided to examine what nursery school teachers think about this topic.

The main objective of this research is to identify problems that ethnolinguistic minorities can encounter in the Serbian education system concerning their right to be educated in their mother tongue or their waiving that right.

Nine employees in the preschool "Poletarac" in Stara Pazova participated in this qualitative research: five of them work in Serbian groups and four of them in Slovak groups.

This research was carried out using an anonymous questionnaire (Appendix 1) to examine nursery school teachers' attitudes towards the conditions for the development of linguistic competences in the aforementioned languages. The questionnaire consists of twelve questions. The method of critical discourse analysis was applied in this research.

The most significant limitation of this work is the number of participants. 


\subsection{Results}

In this chapter we will deal with the answers obtained. The questions were as follows:

1) Have you ever worked with a minority child who does not speak any Serbian or Slovak?

It was found that none of them has worked with a minority child who did not speak any Serbian or Slovak. The informants claimed that in the very beginning some children have difficulties in communicating in Serbian. However, they have overcome that phase quickly. The fact that they use Slovak to communicate with at least one parent helps them acquire language competences in the minority language.

2) Do you consider that minority children going to Serbian groups have developed language competences both in Serbian and Slovak?

All nine informants have answered "yes" without going into details.

3) How do minority children develop their linguistic competences in these two languages?

The informants said that the minority children learn poems both in Serbian and Slovak in preschool. The children also watch cartoons and films in the aforementioned languages. They use it for communication in the family (at least with one parent or grandparent). They also play games with the majority children. When they go to the doctor's or go shopping, they usually use Serbian. To sum up, the informants claim that using Serbian as a majority language in everyday situations or communicating with some family members is what can help them learn it while they use Slovak in the family environment or in preschool if they go to a Serbian group. The nursery school teachers agree that for those children it is easy to use both languages depending on context or situation.

4) Do you know if the children who have gone to the Slovak group start primary school with Serbian/Slovak as the language of instruction?

Most of them start a primary school in Slovak. Different factors influence the parents' decisions: position of the school (the distance from 
home), chances for being educated in one language to the highest level of education, job opportunities, ethnically mixed marriages etc. However, children who went to the Serbian group are more likely to enroll at the Primary School with Serbian as a language of instruction. Rarely do they enroll at the primary school with Slovak as the language of instruction after being educated in Serbian in preschool.

5) Do you consider that a child from Slovak group has reached a certain level of majority language to be able to receive an education in it?

All the nursery teachers said "yes" and explained that it is due to the fact that they are exposed daily to two languages.

6) What kind of difficulties can a minority child encounter receiving an education in Serbian in primary or secondary schools?

The informants claim that minority children can have problems using terms related to Maths, Chemistry, etc. They also have some difficulties when it comes to Serbian grammar (they do not state of which kind) and orthography. When it comes to pronunciation, the minority children have difficulties while pronouncing certain sounds in Serbian.

7) Are you have information on which language or languages a child uses at home?

All nursery school teachers said that they are well informed about the language or languages a child uses in the family and they try to respect it, which is very important.

8) Are there any Serbian children in groups with Slovak as the language of instruction?

There are no Serbian children in groups with Slovak as the language of instruction. Only Slovak children or children coming from mixed marriages go to Slovak groups. The majority of children do not speak Slovak.

9) Are there any activities both in Serbian and Slovak in your preschool? When it comes to the Slovak groups, most activities are in Slovak. However, some poems and fairy tales are in Serbian. 
As far as Serbian groups are concerned, all activities in Serbian. In fact, there are hardly any activities in Slovak during the school year.

10) Do you know if there are any activities that gather Slovak and Serbian groups to foster tolerance toward minority or the majority culture?

The nursery teachers answered that there are some activities during school year, especially before New Year's Eve and the end of the school year. Then, both minority and majority children sing in their mother tongue, act, etc. Nevertheless, those activities take place from time to time. They are not regular. Two informants emphasized that even then Serbian is the dominant language.

11) Has the staff in your preschool undergone additional training through seminars for working in bilingual environments with children whose native languages are different?

There are seminars either in Slovak or Serbian. There are no seminars which deal with the issue of Slovak-Serbian bilingualism in nursery schools.

12) Do you think that there are adequate conditions for development of Slovak- Serbian bilingualism in your preschool?

Most informants said "yes"; but two of them said "no" explaining that there are a lot of disadvantages of children's separation on the basis of language. Two of them did not answer this question.

\subsection{Discussion}

Several practical questions arise when dealing with some issues related to the obtained results. In this part we will discuss some issues related to the obtained results:

1. Is it sufficient to use a minority language only in a family context?

2. Is it possible to acquire academic language competences simply by being exposed to these two languages in a family and in the environment?

3. Why aren't there any special strategies for developing bilingualism? 
The qualitative analysis of the collected data suggests that preschool teachers take the process of developing bilingualism for granted. In other words, they think that a child will reach a certain and sufficient level of proficiency in both languages simply because of being exposed to them. Dialect can be used in rural areas and in everyday communication. However, a literary language should be used in education and in public communication. That is something we ought to explain to our students (Tir, 2009). This is something we should explain to the nursery school teachers, as well. "(...) The language that is necessary in the classroom, particularly as children go through schooling and to the college, is different from the kind of conversational language required to communicate in the shops and streets, when watching the screen, or relaxing with friends" (Baker \& Prys Jones, 1998: 93). To conclude, there is a huge difference between conversational competence and academically contextualized language. This is something our preschool teachers do not seem to know or are not aware of.

The belief that a child will become bilingual because he/she uses the minority language in the family is totally wrong having in mind the next quotation: "Monolingual parents may have bilingual children, while bilingual parents may have monolingual children." (Baker \& Prys Jones, 1998: 29). The language used in preschool or in further education is crucial. If a child receives education in a language which is not his or her mother tongue, the chances are slim for that language to survive in a certain environment because it can lead to its neglect (Skutnab Kangas, 1991: 67).

When it comes to seminars and conferences, there should be special seminars for nursery school teachers working with minority children.

\subsection{Pedagogical implications of this research}

Our findings suggest that employees have the a wrong attitude that a child will reach the same language level in both Serbian and Slovak if exposed to them in their environment. Well-qualified teaching staff in multilingual environments is a very important factor in developing bilingualism (Đuričić, 2013: 549), so it means that people who would work in bilingual settings should receive more information about both cognitive linguistics and sociolinguistics during their studies to be able to work in bilingual or multilingual environments. Their studies should help them develop skills 
for helping minority children learn languages and integrate into society without any special problems and difficulties.

The existing conditions could be significantly improved by implementing additional strategies. It is essential to organize seminars for employees working in bilingual environments and to write manuals with tips for working with children from minority communities etc. This would help children coming from a minority community acquire both their mother tongue and majority language. The aforementioned strategies would also enable the preservation of their own linguistic and ethnic identities, as well as successful integration into society.

\section{Conclusion}

After analyzing the results of this research, we can conclude that the staff working in preschool "Poletarac" in Stara Pazova are not qualified enough when it comes to the linguistic side of their work. In other words, they. the employees. do not recognize the need for creating a special strategy for working with those children. They consider bilingualism as a natural process which will take place in this setting no matter how we treat it in the classroom.

We can also conclude that there are no special strategies for working with minority children in the preschool in Stara Pazova. The lack of seminars, manuals with tips for working with the Slovak minority children living in Serbia can have a negative influence on the development of Slovak-Serbian bilingualism.

Although there are conditions for the development of the SlovakSerbian bilingualism in this town, the results lead to the conclusion that the existing conditions could be significantly improved by implementing additional strategies, such as organizing seminars for employees who work in bilingual environments, and writing manuals with tips for working with children from minority communities. This would help children coming from a minority community to acquire both their mother tongue and the majority language. To conclude, those solutions would also enable the preservation of their own linguistic and ethnic identities, as well as successful integration into society. 


\section{References:}

Baker, C. \& S. Prys Jones. (1998). Encyclopedia of Bilingualism and Bilingual Education. Clevedon: Multilingual Matters.

Baker, C. (2007). Parents' and Teachers' Guide to Bilingualism. Clevedon: Multilingual Matters ( $3^{\text {rd }}$ edition).

De Houwer, A. (2007). Parental language input patterns and children's bilingual use. Applied Psycolinguistics, 28: 411-424.

Đuričić, M. (2013). Uloga roditelja i školskog sistema u održanju manjinskog jezika, sa posebnim osvrtom na područje Vojvodine. Pedagogija, 68(4), 545-553.

Đuričić, M. (2014a). Uloga predškolskih ustanova u održanju manjinskog jezika u dvojezičnim sredinama“". Pedagoška stvarnost. Godina LX, br. 4, 716-722.

Đuričić, M. (2014b). Negovanje slovačko-srpskog bilingvizma u Staroj Pazovi: uslovi u obrazovnom sistemu i stavovi pripadnika slovačke nacionalne zajednice. Zbornik sa V skupa mladih filologa Srbije održanog 30. marta 2013. godine, Kragujevac: FILUM, 421-430.

Filipović, J. (2011). Srpski kao jezik obrazovanja u obrazovanju nacionalnih manjina u Srbiji, u: Vesna Krajišnik (ur.), Srpski kao strani jezik u teoriji i praksi. Beograd: Filološki fakultet, Centar za srpski kao strani jezik, 351-364.

Klemenović, J. \& E. Kamenov. (1998). Komunikacija u dvojezičnoj sredini dečjeg vrtića. U. S. Vasić i dr. (ur.). Jezik i kultura govora $u$ obrazovanju. Beograd: Institut za pedagoška istraživanja, Zavod za udžbenike i nastavna sredstva, 322-335.

Mikeš, M. (1996). Čuvari jezika. Priručnik za rad sa predškolskom decom na jezicima nacionalnih manjina. Beograd: Zavod za udžbenike i nastavna sredstva.

Mikeš, M. (2006). Razvijanje višekulturne ličnosti od malih nogu. U: Ljiljana Subotić (ur). Susret kultura. Novi Sad: Filozofski fakultet, 439-446.

Mikeš, M. (2008). Mali jezikoslovci u vrtiću: razvijanje komunikativnih veština na nematernjem jeziku. Novi Sad: Pedagoški zavod Vojvodine.

Skutnab-Kangas, T. (1991). Bilingvizam da ili ne, Beograd: Zavod za udžbenike i nastavna sredstva. 
Šimoniova-Černakova, R. (2007). Važnost obrazovanja na maternjem jeziku u višejezičnom okruženju. Pedagoška stvarnost, 53(9-10), 819-827.

Tir, M. (2009). Primena kontrastivne lingvistike u nastavi slovačkog jezika kao maternjeg. u: Plemenka Vlahović, Ranko Bugarski \& Vera Vasis (eds.), Višejezični svet Melanije Mikešs. Novi Sad: Filozofski fakultet, Društvo za primenjenu lingvistiku Srbije, 181-187.

\begin{abstract}
This paper analyzes the attitudes of employees in the preschool "Poletarac" in Stara Pazova, a town in the Serbian Province of Vojvodina, with Serbian-Slovak bilingual residents. It examines their attitudes towards the conditions for the development of linguistic competence in the aforementioned languages. Research was carried out using an anonymous questionnaire. The main objective was to identify problems that ethnolinguistic minorities can encounter in the Serbian educational system concerning their right to be educated in their language of primary socialization or their waiving of that right. The results indicate the disadvantages of children's separation on the basis of language and wrong attitudes among employees that children will reach the same language level in both Serbian and Slovak if exposed to them in their environment. The results lead to the conclusion that the existing conditions could be significantly improved by implementing additional strategies, such as organizing seminars for employees who work in bilingual environments, and writing manuals with tips for working with children from minority communities.
\end{abstract}

Keywords: bilingualism, preschools, Serbian, Slovak, Stara Pazova.

\title{
Appendix 1: Questionnaire
}

The questionnaire is completely anonymous. It will be used only to collect data for a paper "The language of instruction issue in pre-schools in bilingual settings: the example of the Slovak ethnolinguistic minority in Stara Pazova". The results of this research will be presented at the International Conference on Minority Languages, held at the Faculty of Philology in Belgrade, in May 2015. 
1. Have you ever worked with a minority child who did not speak any Serbian or Slovak? Please explain.

2. Do you consider that minority children going to Serbian groups have developed language competences both in Serbian and Slovak? Please explain.

3. How do minority children develop their linguistic competences in these two languages? Please explain.

4. Do you know if the children who went to the Slovak group start a primary school with Serbian/Slovak as the language of instruction? Please explain.

5. Do you consider that a child from Slovak group have reached a certain level of majority language to be able to receive education in it? Please explain.

6. What kind of difficulties can encounter a minority child receiving education in Serbian in primary or secondary schools? Please explain. 
7. Are you familiar with the information which language or languages a child uses at home?
a) Yes
b) No

8. Are there any Serbian children in groups with Slovak as the language of instruction?
a) Yes
b) No

9. Are there any activities both in Serbian and Slovak in your preschool? Please explain.

10. Do you know of there are any activities that gather Slovak and Serbian groups to foster tolerance toward minority or the majority culture? Please explain.

11. Has the staff in your preschool undergone additional training through seminars for working in bilingual environments with children whose native languages are different? Please explain.

12. Do you think that there are adequate conditions for development of the Slovak- Serbian bilingualism in your preschool? Please explain.

\section{Biographical statement}

MILICA ĐURIČIĆ, MA, was born in 1988 in Belgrade. She graduated from the Department of Iberian Studies at the Faculty of Philology in 
Belgrade in 2011. She finished her Masters studies at the same faculty in 2012. She started her PhD studies at the Faculty of Philology in Belgrade in 2012. The topic of her doctoral dissertation is: A Critical Approach to the Content of Textbooks for Spanish as a Second Language in Serbia from a Gender Perspective. Since 2013 she has been participating in the research project Knjiženstvo - Theory and History of Women's Writing in Serbian until 1915, financed by the Ministry of Education, Science and Technological Development of the Republic of Serbia. From 2012 to 2015 she worked as a teaching assistant at the Department of Iberian Studies, Faculty of Philology in Belgrade. She has participated in numerous seminars for Spanish teachers as a foreign language in Serbia and Spain. She has presented her work at several scientific conferences in the country. Until this moment she published sixteen papers in national and international scientific journals and conferences independently and in co-authorship. Her areas of interest include sociolinguistics, gender studies and applied linguistics. She speaks Spanish, English and Russian.

E-mail: milica.djuricic@gmail.com 